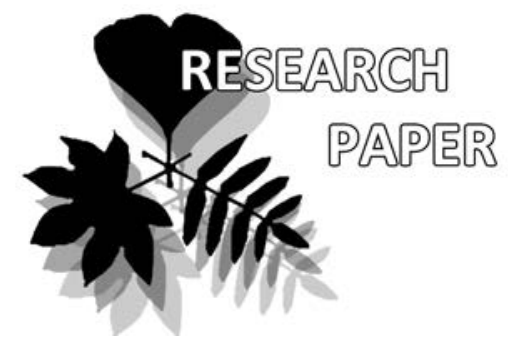

\title{
Subalpine tall-herb vegetation patterns: a case study from the Khamar-Daban Range (southern Baikal region, Eastern Siberia)
}

\author{
Ramona J. Heim ${ }^{1 *} \&$ Victor V. Chepinoga ${ }^{2}$
}

Ramona J. Heim ${ }^{1 *}$

e-mail: ramona.heim@uni-muenster.de

Victor V. Chepinoga ${ }^{2}$

e-mail: victor.chepinoga@gmail.com

${ }^{1}$ Biodiversity and Ecosystem Research Group, Institute of Landscape Ecology, University of Münster, Münster, Germany ${ }^{2}$ V.B. Sochava Institute of Geography SB RAS, Irkutsk, Russia

* corresponding author

Manuscript received: 05.11 .2018

Review completed: 16.02.2019

Accepted for publication: 07.03.2019

Published online: 08.03.2019

\begin{abstract}
A B S T R A C T
In this study, we present the first investigation of diversity and ecology of tall-herb vegetation (class Mulgedio-Aconitetea Hadač \& Klika in Klika \& Hadač 1944) on the Khamar-Daban Range, the generally assumed easternmost distribution limit of this class. We collected data of 162 relevés in the key area of the upper reaches of Bolshoi Mamai River, which is situated on the northern slope of the range. Tall-herb meadows occurred within a large altitudinal range from timberline to the watershed. We found that species richness was positively correlated with inclination and orientation of sites to warmer aspect. In contrast, strong pronounced microtopography and high organic layer thickness led to lower species richness. We divided the tall herb vegetation of the study region into seven community types, which clearly differed in ecological aspects. The results were approved by CCA ordination, which stressed the relation of clusters to elevation, aspect, inclination, microtopography and organic layer.
\end{abstract}

K e y w o r d s : tall-herb vegetation, floristic diversity, high-mountain vegetation ecology, ecological factors

\section{P E 3 Ю M E}

Хайм Р.Ю., Чепинога В.В. Распределение субальпийской высокотравной растительности: исследование на хреб̆те Хамар-Аабан (юг Байкальского региона, Восточная Сибирь). В статье преАставлены результаты первого исследования разнообразия и экологии высокотравной растительности (класс Mulgedio-Aconitetea Hadač \& Klika in Klika \& Hadač 1944) на хребте Хамар-Аабан, который явАяется восточным пределом распространения сообществ этого класса. Нами выполнено 162 геоботанических описания в пределах ключевой территории в верховьях р. Большой Мамай, где высокотравные куга распространены на всем протяжении от границы леса до водраздела. Видовое богатство сообществ положительно коррелирует с крутизной склона и экспозициями, более обеспеченными теплом. Выраженный микрорельеф и мощный органический субстрат, напротив, веАут к снижению виАового разнообразия. При помощи кластерного анализа вылелено семь типов сообществ, хорошо различающихся экологически. Последнее поАтвержАено методом ССА орАинации, показавшей корреляцию выделенных сообществ с такими факторами, как высота наА уровнем моря, экспозиция, уклон, микрорельеф и органический субстрат.

КАючевые слова: высокотравная растительность, флористическое разнообразие, экология высокогорной растительности, экологические факторы
Tall-herb vegetation is strongly influenced by environmental factors (Odland et al. 1995, Karst et al. 2005). Humid and cool climates, as well as nutrient-rich soil conditions are essential for the formation of this vegetation type (Michl et al. 2010). Furthermore, heavy winter precipitation resulting in a long lasting snow layer, which protects the plants from frost, is important for the survival of many species that are part of these communities (Ermakov 2003, Banaš et al. 2010, Sulejman 2011). The complex of all suitable ecological peculiarities which are needed for the development of tall-herb vegetation is found on one hand in mountain ranges of the temperate and the subnemoral zone of the Northern Eurasia (Horvat et al. 1974, RivasMartínez et al. 1984, Grabherr \& Mucina 1993, Ermakov et al. 2000, Kočí 2001, Sulejman 2011, Iakushenko et al.
2012), and on the other hand in the northern boreal zone in suboceanic Europe (MacVean \& Ratcliffe 1962, Odland 1981, Dierßen 1996, Michl et al. 2010). In mountains, this kind of vegetation occurs mainly near, and sometimes above, timberline (Pott 1995, Ellenberg \& Leuschner 2010). In the higher mountains of Southern Siberia, tall-herb vegetation is substituted by short-herb alpine meadows, or, in more arid conditions, by tundra vegetation (Ermakov et al. 2000).

The phytodiversity of the South Siberian Mountains is the greatest in Siberia (Malyshev et al. 1999, Belov et al. 2015). Tall-herb vegetation is phytosociologically treated within the Eurosiberian class Mulgedio-Aconitetea Hadač \& Klika in Klika \& Hadač 1944 (Ermakov et al. 2000) and consists out of tall-forb, tall-grass, and tall-fern 
communities. So far, more than 50 associations of Mulgedio-Aconitetea are described from Southern Siberia, mainly from the western part of Altai-Sayan Mts., i.e. the Altai, Western Sayan, Kuznetsky Alatau, and western margin of the Eastern Sayan (Lashchinskiy \& Gorshkova 1995, Ermakov et al. 2000, Ermakov 2003, Zibzeev 2010a, 2010b, 2012, Zibzeev \& Basargin 2012).

Khamar-Daban is the range on the south of Baikal rift zone, which is considered the easternmost limit of community types belonging to the class, but there is only few data available from the region (Guinochet 1982, Chytrý et al. 1993, Chytrý et al. 1995, Danihelka \& Chytrý 1995, Valachovič et al. 2002).

Despite the number of publications devoted to the syntaxonomy (e. g. Ermakov et al. 2000), there is a lack of publications analyzing ecological distribution patterns of the tall-herb meadows in Southern Siberia. Communities of this biome in Siberia are influenced by continental climate, in contrast to the European ones (Ermakov 2003). Therefore, the features of Siberian tall-herb vegetation are of great interest for the understanding of ecological preferences, limits and capabilities of this type of grassland in general. Ecological studies, focusing on environmental factors and community ecology, are essential for a comprehensive description of vegetation of the continental regions of Asia.

With the intention to reveal vegetation patterns of sub alpine tall-herb communities on the northern slope of the Khamar-Daban Range, we addressed following questions:

1. Which environmental variables influence species diversity of tall-herb vegetation on the northern slope of the Khamar-Daban Range?

2. How many community types can be differentiated for tall-herb vegetation in local area, floristically? And which species are indicators for those community types?

3. Are the different community types reflected by environmental variables?

\section{STUDY AREA}

The study area is situated in the east of Southern Siberia, $8 \mathrm{~km}$ from Lake Baikal on the northern slope of the Khamar-Daban Range in the upper reaches of the Bolshoi Mamai River, a small tributary of Lake Baikal, and covers a total area of $6.5 \mathrm{~km}^{2}$ (Fig. 1). Southern Siberia in general, is a predominantly mountainous territory with vast AltaiSayan Mts. (Strelkov \& Vdovin 1969) on the southwest, which turn north-eastwards through the Baikal rift zone to the Stanovoy Range (Florensov 1974). These mountains are links in a transcontinental mountain chain, which stretches from Central Asia to the Beringia (Florensov 1974).

We collected data from timberline (about $900 \mathrm{~m}$ a.s.l.) to the top, where two sources of the Bolshoi Mamai River's watershed are found. The two highest peaks in the area, Polyana Mt. (1756 $\mathrm{m}$ a.s.l., $\left.51.362400^{\circ} \mathrm{N}, 104.862447^{\circ} \mathrm{E}\right)$, and Mamai Mt. (1541 $\mathrm{m}$ a.s.l., $\left.51.387197^{\circ} \mathrm{N}, 104.807840^{\circ} \mathrm{E}\right)$ are located in the south and in the west, respectively. Taking into account differences in definitions of "subalpine" by different authors (Körner 1998), we implement the subalpine belt as the transition zone between the upper limit of the closed mountain forest and the upper limit of tree spe-

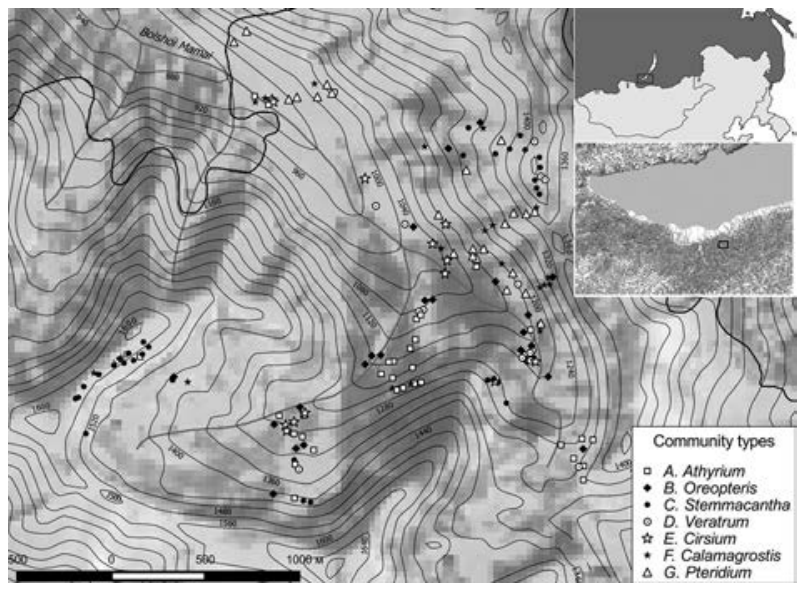

Figure 1 Localities of sample plots in upper reaches of the Bolshoi Mamai River (Khamar-Daban Range, Southern Baikal region). The timberline position is marked by the black bold line

cies distribution. In our study area, the distribution of tallherb meadows lies within this subalpine belt.

The northern slope of the Khamar-Daban Range is composed of metamorphosed Proterozoic complexes covered by basalts (Florensov \& Olyunin 1965). Sharp smaller ranges shaped by cryogenic and periglacial processes extend northwards from main mountain chain. Steep slopes (30$45^{\circ}$ ) are dissected by deep valleys.

The territory is characterized by a short and cold summer (mean July temperature: $12.7^{\circ} \mathrm{C}$ ) and a long, comparatively cold (mean January temperature: $17.9^{\circ} \mathrm{C}$ ) winter (Ladeishchikov et al. 1977).

The Khamar-Daban Range is one of the ranges that form the rift zone around Lake Baikal. It stretches over $350 \mathrm{~km}$ from the south-western end of the lake (next to Kultuk town) to the Selenga River valley on the east. Sublatitudinal orientation of the range defines its barrier function on the way of the air masses, which are transferring from the Atlantic Ocean and form the climate of the western Baikal region. The central part of the northern slope of the Khamar-Daban Range intercepts the greatest amount of precipitation in the region. The only mountain meteorological station located on the western end of the KhamarDaban Range recorded an average precipitation of $1443 \mathrm{~mm}$ per year (Ladeishchikov et al. 1977).

High precipitation in winter leads to a thick snow cover, which is usually more than $100 \mathrm{~cm}$ deep with a maximum of $190 \mathrm{~cm}$ (Ladeishchikov et al. 1977). The area on Bolshoi Mamai is covered by snow for at least 8 months: from the end of September until the beginning of June (personal observations). High air humidity during summer and thick snow cover during winter, provide favorable conditions for tall-herb vegetation, despite the mean annual temperature until $-3.4^{\circ} \mathrm{C}$ (Aleksandrova et al. 1977).

The forest belt is found at lower elevations (460-600 m a.s.l.) and is composed by mixed dark coniferous forests (Abies sibirica, Picea obovata, Pinus sibirica) together with smallleaved birch (Betula platyphylla, B. cf. pubescens) and aspen (Populus tremula) on disturbed areas. Pinus sibirica predominates in mountain taiga, which is found at elevations of 
600-800 $\mathrm{m}$ a.s.l. The upper part of the forest belt is occupied by $A$. sibirica forests accompanied by $P$. sibirica.

The range is of high refugial value for many endangered and relict mesophytic plant species absent in other parts of Baikal Siberia (Tubanova et al. 2016, Chepinoga et al. 2017). Weak human influence is typical for the mountainous highlands around Lake Baikal and contributes to the conservation of poorly disturbed subalpine vegetation.

\section{MATERIAL AND METHODS Sampling design}

The original data set consists of 162 relevés that were sampled during the second half of July 2015. Seven relevés were sampled on the 22nd July 2014. We recorded the vegetation on plots of $25 \mathrm{~m}^{2}$ located in representative sites. A percentage scale was used to determine plant cover. Elevation, aspect, inclination, microtopography, and thickness of organic layer (namely, O (organic) horizon) were also determined (Table 1). The term microtopography was used as ordinal variable to describe the unevenness of the ground surface (stones, protruding rhizomes, etc.), and was determined visually by estimating the difference between height of hummocks and depressions within the plot. Inclination was estimated visually as well, while we used compass and GPS navigator for determination of aspect and elevation. Aspect data were transformed to linear values $\left(40^{\circ}=0\right.$, $\left.220^{\circ}=180\right)$ because of the influence of the sun, neglecting east and west aspect (Dargie 1984, Elliott et al. 1999). Korolyuk (2006) indicator values were used for soil moisture (120 grades in full scale) and soil richness (available mineral nutrition; 30 grades) scores for every sample plot.

\section{Data analysis}

Data processing was carried out using the software package IBIS (Integrated Botanical Information System), the vegetation database management software (Zverev 2007, 2012). For statistical analyses R, Version 3.5.1. (R Core Team 2018), was used.

We analyzed interactions between species richness (dependent variable) and environmental factors (independent variables) using a general linear model assuming Poisson distribution:

Species richness $\sim$ Elevation + Aspect + Slope + Organic Layer + Microtopography

Table 1: Variation of sampled environmental variables.

\begin{tabular}{lll}
\hline Variable & Unit & Range \\
\hline Inclination & degree & $0-45$ \\
Elevation (above sea level) & m & $899-1589$ \\
Aspect & degree & $0-360$ \\
Aspect (modified) & degree & $0-180$ \\
Microtopography & $\mathrm{cm}$ & $0-50$ \\
Thickness of organic layer & $\mathrm{cm}$ & $0-12$ \\
Soil moisture (after Korolyuk 2006) & grades & $61.1-74.2^{*}$ \\
Soil richness (after Korolyuk 2006) & grades & $9.8-11.7^{*}$ \\
\hline * The full scale of indicator value for mosture consists of 120 \\
grades, and for soil richness (namely available mineral nutrition) \\
- 30 grades.
\end{tabular}

Significant variables were selected with help of "backward selection" ( $p<0.05$ ) (Crawley 2013). Normal distribution and variance homogeneity of residuals was graphically tested with help of a normal probability plot (Dormann \& Kühn 2009, Crawley 2013).

We divided vegetation data into community types using hierarchical agglomerative cluster-analysis using Sørensen (Bray-Curtis) indices and the Ward's-method (Ward 1963, Oksanen et al. 2018). Incomplete cases with NAs were removed. The number of clusters was determined by optimum average silhouette width; package "fpc" (Rousseeuw 1987, Hennig 2018). Clustering algorithm output was described by the correlation between the cophenic distances and the original distances (Sneath \& Sokal 1973). We analyzed community integrity with package "labdsv" (Roberts 2016). With the packages "ggplot2” (Wickham 2009), "ggdendro" (Vries \& Ripley 2016), "plyr" (Wickham 2011) and "zoo" (Zeileis \& Grothendieck 2005) the cluster analysis was visualized.

For community types, we determined indicator species by Dufrene-Legendre Indicator Species Analysis, using frequency tables and mean abundance (Indicator Value, $\mathrm{p}<0.05$ ) (Dufrene \& Legendre 1997). Because of a lack of vegetation classification for the range and small size of the key area we avoided to link identified units to the concrete syntaxa. All distinguished community types are accepted as unranked communities belonging to the class MulgedioAconitetea Hadač \& Klika in Klika \& Hadač 1944. Besides standard packages, the package "vegan" was used for statistical analyses of community ecology (Oksanen et al. 2018).

The significant environmental variables, which should be included in the correspondence analysis, were a priori selected with "backward selection" ( $p<0.05)$ (Crawley 2013). Only plant species that occurred in at least four plots were included in the analysis ( $\mathrm{n}=69$ remaining species). Additionally, we performed a square root transformation of cover values. After performing a DCA, which showed a first axis length of $4.45 \mathrm{SD}$ unit, indicating unimodal response model with almost complete turnover in species composition we chose CCA (Leyer \& Wesche 2007, Dormann \& Kühn 2009) as appropriate method.

Moreover, differences between groups in regard to the environmental variables, as well as other important factors like species richness and vegetation height, were determined with the Kruskal-Wallis-test $(\mathrm{p}<0.05)$ (Fahrmeir et al. 2016).

\section{Nomenclature}

The nomenclature of taxa mainly follows Chepinoga et al. (2008) for vascular plants, Ignatov et al. (2006) for mosses, and Konstantinova \& Bakalin (2009) for liverworts.

\section{RESULTS \\ Floristic diversity}

The number of taxa (species and subspecies of vascular plants and bryophytes) recorded in 162 relevés consisted out of 132 species. Only 30 species exceeded the $1 \%$ constancy and 24 species exceeded $2 \%$. Top ranking were (in brackets constancy percentage values) Geranium krylovii (86), 
Veratrum lobelianum (70), Poa ircutica (67), Calamagrostis langsdorffii (66), Lilium pilosiusculum (55), Athyrium distentifolium (53), Rumex alpestris (49), Solidago daburica (49), Trollius cf. kytmanovii (41), Doronicum altaicum (40), Anemone baicalensis (39), Poa sibirica (38), Chamaenerion angustifolium (36), Maianthemum bifolium (35), Stemmacantha carthamoides (35).

Species diversity of individual plots varied between 6 and 37 species, depending on the community type. In addition to that, species diversity was positively correlated with inclination and orientation of plots to warmer (south and south-west) aspect, but negatively correlated with microtopography and organic layer thickness. The independent variable "Elevation" was excluded from the initial model as statistically insignificant (Table 2, Fig. 2).

\section{Community types}

Due to analysis of silhouette width, data were separated by hierarchical agglomerative cluster analysis into seven clusters (Fig. 3). The correlation between cophenetic distances and original data was 0.47 . The established clusters were characterized by 45 significant indicator species (Table 3 ). The clusters differed significantly regarding species diversity and ecological factors, except the total cover of the herb layer (Fig. 4). The established clusters were considered as unranked communities of the class Mulgedio-Aconitetea (Table 3).

The Athyrium distentifolium-comm. (cluster A) was branching off from the main tree first, and is floristically most distinct from other tall-herb vegetation, in our study. It included communities characterized by the dominance of Athyrium distentifolium. In addition to this species, Doronicum altaicum was distinguished as a second indicator species. These communities were the poorest in species diversity. A. distentifolium stands occurred at medium elevations (mainly within 1200 and $1300 \mathrm{~m}$ a.s.l.) and at intermediate inclinations $10-20^{\circ}$ of warmer west and south-west aspect. They occupy one of the poorest (concerning available mineral nutrition), often stony soils. The presence of big stones within plots lead to a strongly pronounced microtopography, with the highest differences between hummocks and depressions in comparison with other tall-herb meadows.

The Oreopteris limbosperma-comm. (cluster B) corresponded to stands with a well pronounced dominance of Oreopteris limbosperma. Other two indicator species (Maianthemum bifolium and Anemone sibirica) had lower abundance and the species diversity was relatively low in comparison to other communities. Similar to the Atbyrium distentifolium-community, stands of Oreopteris limbosperma were also found at medium elevations, but they occurred on steeper but smoother slopes in a broader range of aspect at poor soils. In case of the Oreopteris limbosperma-comm., microtopography was formed mainly by rhizomes of O. limbosperma protruding above the ground. The height of fronds was also lower and usually not exceeds $60 \mathrm{~cm}$.

The cluster C (Stemmacantha carthamoides-comm.) composed together with clusters D (Veratrum lobelianum-comm.) and $\mathrm{E}$ (Cirsium helenioides-comm.) the central main subclade within the tree. The Stemmacantha carthamoides-comm. was characterized by the highest species diversity. As indica-
Table 2. Impact of aspect, slope, microtopography and organic layer drought on number of species. The minimal adequate model explains $40 \%$ of the variance.

\begin{tabular}{lll}
\hline Independent variable & $\mathbf{p}$ & $\mathbf{C h i}^{2}{ }_{1,102}$ \\
\hline Aspect & $<0.01$ & 14.26 \\
Inclination & $<0.01$ & 17.79 \\
Microtopography & 0.011 & 6.33 \\
Organic layer & 0.021 & 15.31 \\
Elevation & 0.13 & -2.28 \\
\hline
\end{tabular}
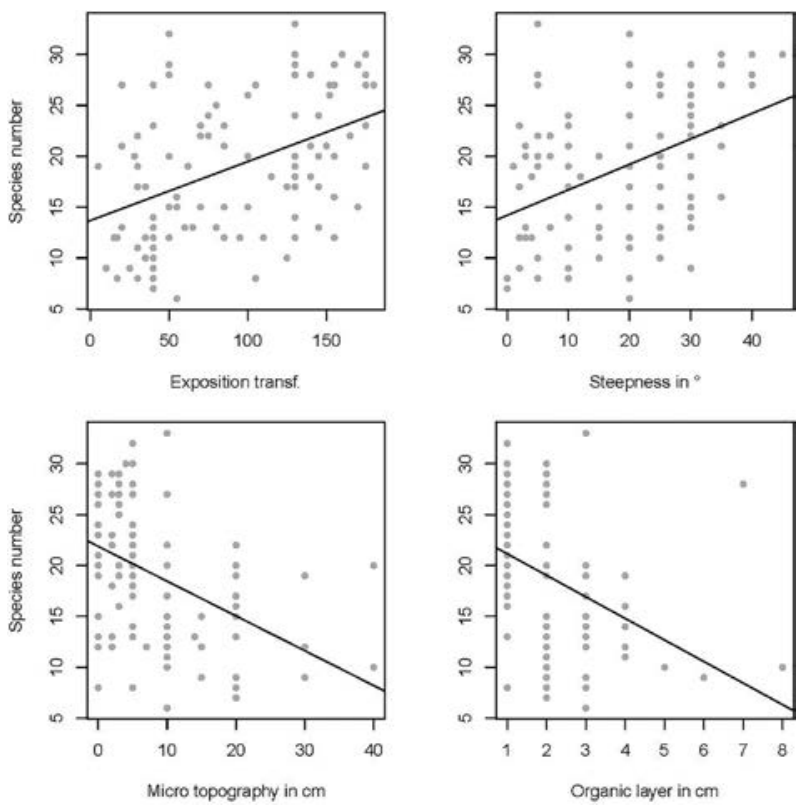

Figure 2 Number of species per plot according to the transformed aspect, slope inclination, microtopography and organic layer

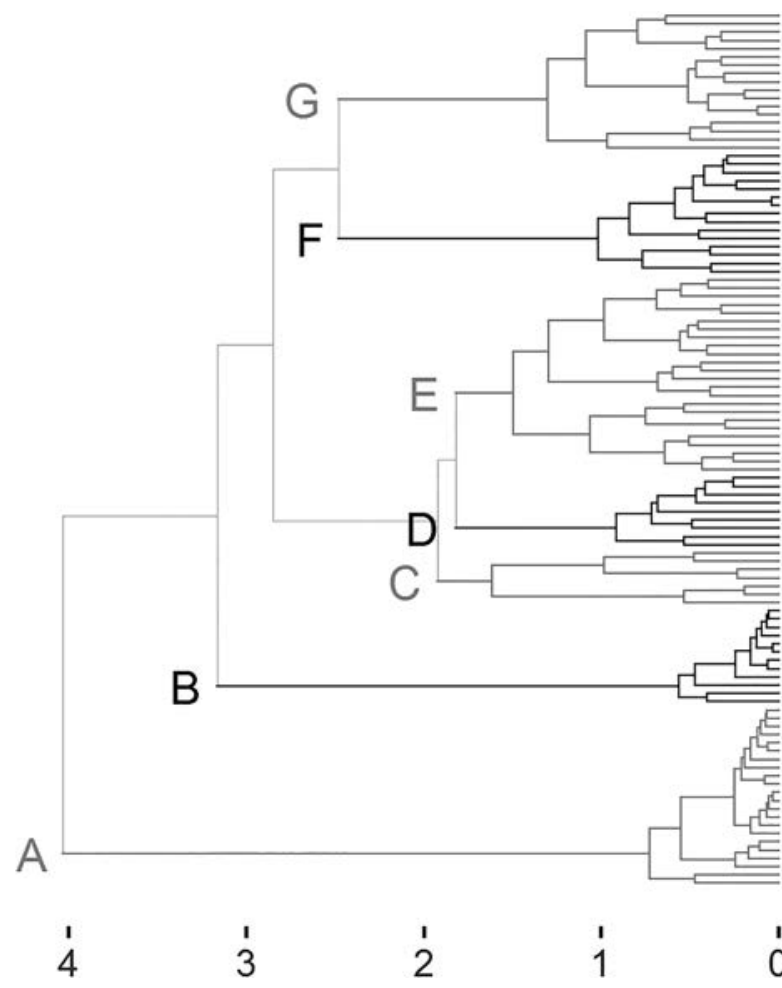

Figure 3 Dendrogram of the cluster analysis (Sørensen (Bray-Curtis) index, Ward's method) for 162 relevés of tall-herb meadows in upper reaches of the Bolshoi Mamai River. For names of the clusters (community types) see Fig. 1 

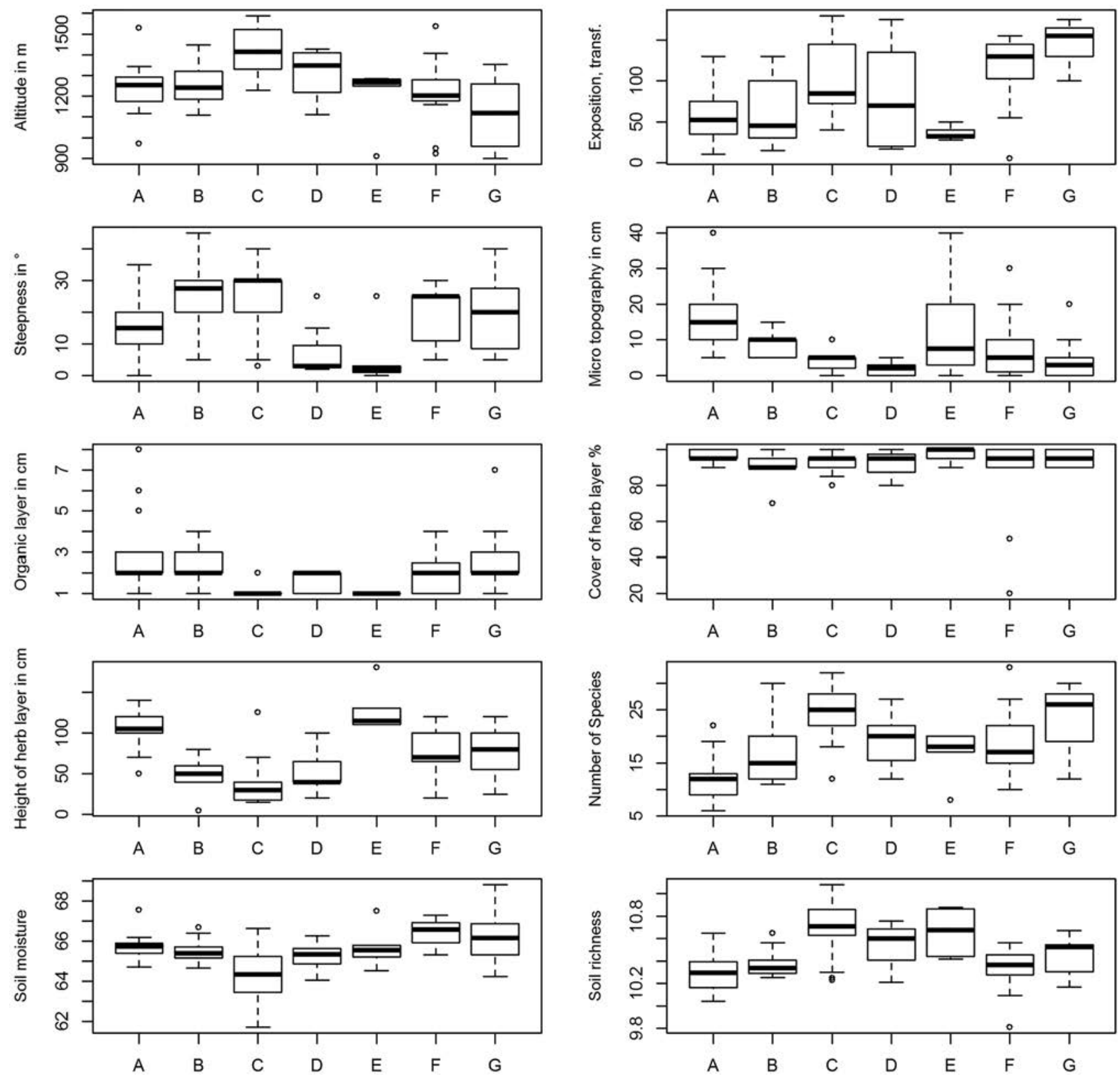

Figure 4 Ecological parameters and species richness of the established clusters. For names of the clusters (community types) see Fig. 1

tor species, 18 taxa have been distinguished. Stemmacantha carthamoides, Anthoxanthum alpinum, Dracocephalum grandiflorum, and Saussurea latifolia have highest indicator values. Besides this, these species are among the most abundant indicator species within unit. Tall-herb vegetation of the Stemmacantha carthamoides-comm. occupied highest elevations and steepest slopes of warmer south-east and south-west aspect. Soil moisture was comparatively low, whereas the available mineral nutrition was highest compared to other community types. The microtopography was weakly pronounced as well as the organic layer. Additionally, the mean height of herb layer of the Stemmacantha carthamoides-comm. stands was very low and did generally not exceed $40 \mathrm{~cm}$.

The Veratrum lobelianum-comm. (cluster D) was very peculiar in species composition. Three species have been distinguished as indicator ones. Among them, Poa ircutica, the South Siberian endemic species, and Swertia baicalensis - a local endemic of the Khamar-Daban Range. This vegetation type occured on higher elevations but on more gentle and smooth slopes of different aspect. Rich soils with medium soil moisture characterized this cluster. Like the Stemmacantha carthamoides-comm., height of herb layer in stands of Veratrum lobelianum-comm. was low.

The physiognomy of communities belonging to cluster E (Cirsium helenioides-comm.) was determined by Cirsium belenioides, Aconitum rubicundum and Delphinium elatum, which were the dominant or codominant species on plots of this community type. Beyond these three species, eight others have been determined also as indicator species including highly indicative Saxifraga aestivalis. Habitats of this community had the largest range of microtopography associated with the presence of large stones on plots and often stretched along streams and streamlets with moderately moist soils with rich available mineral nutrition but thin organic 
Table 3. Results of the indicator species analysis of units revealed in subalpine meadows of Bolshoi Mamai. Numbers indicate percentage occurrence frequency (constancy), supercase numbers indicate mean cover (in \%, "+" indicates values $<0.1$ ), gray shading indicates indicator species. The table includes only species that have an indicator value of 0.25 or higher, indicator species with an indicator value of 0.5 or higher are shown in bold. Significance levels (p) are following: $* * *<0.001$, $* *<0.01, *<0.05$, n.s. - not significant. For names of the clusters (community types) see Fig. 1.

\begin{tabular}{|c|c|c|c|c|c|c|c|c|c|}
\hline Clusters & $\mathbf{A}$ & $\mathbf{B}$ & $\mathrm{C}$ & $\mathbf{D}$ & $\mathbf{E}$ & $\mathbf{F}$ & G & \multirow{3}{*}{$\begin{array}{l}\text { Indicator } \\
\text { value }\end{array}$} & \multirow{3}{*}{$\mathrm{p}$} \\
\hline Number of relevés & 35 & 25 & 32 & 14 & 13 & 19 & 24 & & \\
\hline Total number of species & 52 & 68 & 92 & 55 & 50 & 69 & 87 & & \\
\hline $\begin{array}{l}\text { Athyrium distentifolium-comm. } \\
\text { Athyrium distentifolium } \\
\text { Doronicum altaicum }\end{array}$ & $\begin{array}{c}100^{84.17} \\
66^{1.63}\end{array}$ & $\begin{array}{c}36^{1.74} \\
48^{+}\end{array}$ & $\begin{array}{c}34^{1.04} \\
31^{+}\end{array}$ & $\begin{array}{l}71^{2.59} \\
50^{0.38}\end{array}$ & $\begin{array}{l}23^{2.77} \\
46^{0.78}\end{array}$ & $\begin{array}{c}58^{24.58} \\
16^{0.32}\end{array}$ & $\begin{array}{c}29^{0.5} \\
13^{0.13}\end{array}$ & $\begin{array}{l}0.86 \\
0.31\end{array}$ & $\begin{array}{l}* * * \\
* *\end{array}$ \\
\hline $\begin{array}{l}\text { Oreopteris limbosperma-comm. } \\
\text { Oreopteris limbosperma } \\
\text { Maianthemum bifolium } \\
\text { Anemone sibirica }\end{array}$ & $\begin{array}{l}17^{0.86} \\
31^{0.21}\end{array}$ & $\begin{array}{c}100^{77.32} \\
76^{0.68} \\
12^{+}\end{array}$ & $\begin{array}{l}31^{0.96} \\
16^{0.16} \\
72^{8.94}\end{array}$ & $\begin{array}{c}50^{0.8} \\
43^{0.17} \\
14^{+}\end{array}$ & $8^{+}$ & $\begin{array}{c}16^{0.32} \\
37^{0.28} \\
5^{0.16}\end{array}$ & $\begin{array}{c}4^{+} \\
33^{0.38} \\
13^{+}\end{array}$ & $\begin{array}{l}0.96 \\
0.27 \\
0.69\end{array}$ & $\begin{array}{l}* * * \\
* * \\
* * *\end{array}$ \\
\hline $\begin{array}{l}\text { Stemmacantha carthamoides-comm. } \\
\text { Stemmacantha carthamoides } \\
\text { Anthoxanthum alpinum } \\
\text { Dracocephalum grandiflorum } \\
\text { Saussurea latifolia } \\
\text { Vaccinium myrtillus } \\
\text { Hieracium krylovii } \\
\text { Dianthus sajanensis } \\
\text { Solidago dahurica } \\
\text { Aquilegia glandulosa } \\
\text { Campanula rotundifolia } \\
\text { Phlojodicarpus villosus } \\
\text { Sanguisorba officinalis } \\
\text { Callianthemum sajanense } \\
\text { Trollius cf. kytmanovii } \\
\text { Geranium krylovii } \\
\text { Campanula glomerata } \\
\text { Pedicularis incarnata } \\
\text { Galium boreale }\end{array}$ & $\begin{array}{c}3^{+} \\
\cdot \\
\cdot \\
3^{+} \\
\cdot \\
\cdot \\
23^{+} \\
9^{+} \\
\cdot \\
\cdot \\
\cdot \\
\cdot \\
94^{3 \cdot 1} \\
\cdot \\
3^{+}\end{array}$ & $\begin{array}{c}20^{1.92} \\
16^{+} \\
\cdot \\
32^{0.89} \\
24^{+} \\
20^{+} \\
4^{+} \\
64^{0.13} \\
32^{0.18} \\
8^{+} \\
4^{+} \\
\cdot \\
\cdot \\
\cdot \\
96^{3.46} \\
8^{+} \\
20^{+} \\
24^{+}\end{array}$ & $\begin{array}{l}97^{19.79} \\
66^{1.67} \\
56^{1.2} \\
91^{6.73} \\
72^{3.54} \\
84^{0.96} \\
72^{+} \\
91^{2.81} \\
81^{1.03} \\
50^{0.19} \\
38^{1.61} \\
34^{8.66} \\
34^{0.92} \\
22^{0.76} \\
94^{12.28} \\
44^{0.13} \\
66^{0.24} \\
59^{0.24}\end{array}$ & $\begin{array}{c}43^{4.44} \\
29^{+} \\
7^{+} \\
36^{+} \\
50^{0.39} \\
43^{0.18} \\
14^{+} \\
86^{0.84} \\
57^{0.39} \\
\cdot \\
\cdot \\
\cdot \\
\cdot \\
7^{0.14} \\
86^{7.02} \\
7^{+} \\
29^{+} \\
14^{+}\end{array}$ & $\begin{array}{c}\cdot \\
\cdot \\
\cdot \\
\cdot \\
\cdot \\
62^{1.38}\end{array}$ & $\begin{array}{c}37^{2.12} \\
11^{+} \\
\cdot \\
58^{0.75} \\
26^{+} \\
37^{0.44} \\
11^{+} \\
84^{0.93} \\
21^{0.26} \\
5^{+} \\
\cdot \\
\cdot \\
11^{+} \\
\cdot \\
74^{3.58} \\
16^{+} \\
47^{+} \\
32^{0.13}\end{array}$ & $\begin{array}{c}33^{0.47} \\
13^{+} \\
17^{+} \\
50^{0.77} \\
25^{1.13} \\
38^{0.19} \\
17^{+} \\
71^{0.58} \\
25^{0.22} \\
8^{+} \\
4^{+} \\
4^{+} \\
13^{+} \\
\cdot \\
79^{5.13} \\
33^{+} \\
33^{0.18} \\
79^{0.15}\end{array}$ & $\begin{array}{l}0.67 \\
0.59 \\
0.52 \\
0.50 \\
0.49 \\
0.44 \\
0.44 \\
0.41 \\
0.40 \\
0.38 \\
0.36 \\
0.34 \\
0.34 \\
0.33 \\
0.32 \\
0.29 \\
0.27 \\
0.25\end{array}$ & $\begin{array}{l}* * * \\
* * * \\
* * * \\
* * * \\
* * * \\
* * * \\
* * * \\
* * * \\
* * * \\
* * * \\
* * * \\
* * * \\
* * * \\
* * \\
* * \\
* * \\
* * \\
*\end{array}$ \\
\hline $\begin{array}{l}\text { Veratrum lobelianum-comm. } \\
\text { Veratrum lobelianum } \\
\text { Poa ircutica } \\
\text { Swertia baicalensis }\end{array}$ & $\begin{array}{c}86^{1.41} \\
91^{4.19} \\
14^{+}\end{array}$ & $\begin{array}{c}56^{1.25} \\
80^{3.38} \\
60^{1.1}\end{array}$ & $\begin{array}{l}66^{1.44} \\
69^{4.92} \\
53^{2.39}\end{array}$ & $\begin{array}{c}100^{51.43} \\
86^{10.86} \\
64^{2.59}\end{array}$ & $\begin{array}{c}54^{0.26} \\
46^{0.7}\end{array}$ & $\begin{array}{l}63^{0.98} \\
42^{3.74} \\
16^{0.11}\end{array}$ & $\begin{array}{c}63^{1.15} \\
38^{2.05} \\
4^{0.42}\end{array}$ & $\begin{array}{l}0.89 \\
0.31 \\
0.25\end{array}$ & $\begin{array}{l}* * * \\
* * \\
* *\end{array}$ \\
\hline $\begin{array}{l}\text { Cirsium belenioides-comm. } \\
\text { Cirsium helenioides } \\
\text { Aconitum rubicundum } \\
\text { Saxifraga aestivalis } \\
\text { Delphinium elatum } \\
\text { Caltha palustris } \\
\text { Urtica dioica } \\
\text { Angelica decurrens } \\
\text { Sciurohypnum reflexum, ml } \\
\text { Lescuraea patens, ml } \\
\text { Heracleum dissectum } \\
\text { Thalictrum minus }\end{array}$ & $\begin{array}{c}11^{+} \\
23^{1.32} \\
14^{0.12} \\
\cdot \\
\cdot \\
\cdot \\
\cdot \\
\cdot \\
26^{0.19} \\
3^{+}\end{array}$ & $\begin{array}{c}12^{+} \\
12^{+} \\
4^{+} \\
\cdot \\
\cdot \\
\cdot \\
\cdot \\
\cdot \\
4^{+} \\
4^{+}\end{array}$ & $\begin{array}{c}6^{+} \\
13^{0.13} \\
9^{+} \\
\cdot \\
\cdot \\
\cdot\end{array}$ & $\begin{array}{c}14^{+} \\
\cdot \\
\cdot \\
\cdot \\
. \\
. \\
. \\
. \\
\cdot\end{array}$ & $\begin{array}{l}92^{45.17} \\
92^{25.93} \\
77^{1.02} \\
54^{11.54} \\
38^{0.42} \\
31^{0.25} \\
31^{3.15} \\
31^{3.69} \\
31^{2.23} \\
46^{3.01} \\
38^{0.62}\end{array}$ & $\begin{array}{c}26^{0.38} \\
26^{1.59} \\
5^{+} \\
\cdot \\
\cdot \\
\cdot \\
\cdot \\
\cdot \\
\cdot \\
16^{0.43} \\
32^{+}\end{array}$ & $\begin{array}{c}21^{0.3} \\
21^{1.59} \\
\cdot \\
\cdot \\
\cdot \\
\cdot \\
\cdot \\
\cdot \\
25^{0.89} \\
33^{0.11}\end{array}$ & $\begin{array}{l}0.91 \\
0.78 \\
0.68 \\
0.54 \\
0.38 \\
0.31 \\
0.31 \\
0.31 \\
0.31 \\
0.30 \\
0.27\end{array}$ & $\begin{array}{l}* * * \\
* * * \\
* * * \\
* * * \\
* * * \\
* * * \\
* * * \\
* * * \\
* * * \\
* * \\
* *\end{array}$ \\
\hline $\begin{array}{l}\text { Calamagrostis purpurea-comm. } \\
\text { Calamagrostis langsdorffi } \\
\text { Chamaenerion angustifolium } \\
\text { Lilium pilosiusculum }\end{array}$ & $\begin{array}{l}77^{4.04} \\
31^{0.44} \\
66^{0.17}\end{array}$ & $\begin{array}{l}56^{0.85} \\
32^{0.1} \\
36^{+}\end{array}$ & $\begin{array}{l}19^{1.1} \\
19^{0.32} \\
28^{0.18}\end{array}$ & $\begin{array}{c}71^{2.65} \\
43^{0.46} \\
71^{+}\end{array}$ & $\begin{array}{l}85^{4.85} \\
38^{0.11} \\
54^{0.12}\end{array}$ & $\begin{array}{l}100^{58.42} \\
63^{5.23} \\
68^{0.72}\end{array}$ & $\begin{array}{l}83^{4.6} \\
42^{1.89} \\
75^{0.34}\end{array}$ & $\begin{array}{l}0.76 \\
0.39 \\
0.29\end{array}$ & $\begin{array}{c}* * * \\
* * * \\
*\end{array}$ \\
\hline $\begin{array}{l}\text { Pteridium aquilinum-comm. } \\
\text { Pteridium aquilinum } \\
\text { Angelica sylvestris } \\
\text { Rubus saxatilis } \\
\text { Poa sibirica } \\
\text { Carex macroura }\end{array}$ & $\begin{array}{l}6^{0.6} \\
3^{+} \\
\cdot \\
6^{0.15} \\
\end{array}$ & $\begin{array}{c}20^{2.88} \\
8^{+} \\
8^{+} \\
16^{0.2} \\
8^{0.2}\end{array}$ & $\begin{array}{c}9^{0.94} \\
6^{+} \\
6^{0.47} \\
81^{1.33} \\
44^{0.7}\end{array}$ & $\begin{array}{l}21^{2.86} \\
7^{0.21} \\
43^{0.66} \\
7^{0.21}\end{array}$ & $\begin{array}{l}8^{+} \\
8^{+} \\
8^{+}\end{array}$ & $\begin{array}{c}68^{11.05} \\
37^{0.18} \\
16^{+} \\
21^{0.33}\end{array}$ & $\begin{array}{c}100^{64.71} \\
63^{0.91} \\
58^{2.27} \\
75^{1.8} \\
38^{2.88}\end{array}$ & $\begin{array}{l}0.78 \\
0.51 \\
0.43 \\
0.30 \\
0.27\end{array}$ & $\begin{array}{l}* * * \\
* * * \\
* * * \\
* * \\
* *\end{array}$ \\
\hline $\begin{array}{l}\text { Diagnostic species of the order Tro } \\
\text { Pleurospermum uralense } \\
\text { Crepis lyrata } \\
\text { Jacobaea nemorensis } \\
\text { Crepis sibirica } \\
\text { Lamium album } \\
\text { Bupleurum aureum } \\
\text { Anthriscus sylvestris } \\
\text { Milium effusum } \\
\text { Myosotis palustris }\end{array}$ & $\begin{array}{c}\text { llio-Crep } \\
3^{0.14} \\
11^{+} \\
3^{+} \\
23^{+} \\
6^{+} \\
3^{+} \\
3^{+} \\
\end{array}$ & $\begin{array}{c}\text { detalia sil } \\
4^{+} \\
8^{+} \\
4^{+} \\
16^{+} \\
12^{+} \\
24^{0.29} \\
\cdot \\
\cdot \\
\cdot\end{array}$ & $\begin{array}{c}\text { ricae } \\
22^{0.2} \\
19^{+} \\
6^{+} \\
13^{+} \\
3^{+} \\
47^{0.32} \\
3^{+}\end{array}$ & $\begin{array}{c}14^{+} \\
7^{+} \\
\cdot \\
\cdot \\
7^{+} \\
7^{+} \\
\cdot \\
7^{+} \\
\cdot\end{array}$ & $\begin{array}{c}15^{+} \\
15^{+} \\
8^{+} \\
46^{+} \\
\cdot \\
23^{0.78} \\
\cdot \\
8^{+}\end{array}$ & $\begin{array}{c}16^{+} \\
11^{+} \\
32^{0.28} \\
42^{0.38} \\
42^{+} \\
42^{0.38} \\
16^{+} \\
\cdot \\
\cdot\end{array}$ & $\begin{array}{c}17^{+} \\
17^{+} \\
8^{+} \\
46^{0.32} \\
33^{+} \\
58^{0.17} \\
4^{+} \\
. \\
.\end{array}$ & & $\begin{array}{l}\text { n.s. } \\
\text { n.s. } \\
\text { n.s. } \\
\text { n.s. } \\
\text { n.s. } \\
\text { n.s. } \\
\text { n.s. } \\
\text { n.s. } \\
\text { n.s. }\end{array}$ \\
\hline $\begin{array}{l}\text { Diagnostic species of the order } S c h \\
\text { Diphasiastrum alpinum } \\
\text { Gnaphalium norvegicum }\end{array}$ & bulzio cri & $\begin{array}{l}e-A q u i \\
4^{+}\end{array}$ & $\begin{array}{c}\text { gietaliag } \\
16^{+} \\
6^{+}\end{array}$ & $\begin{array}{l}\text { adulosae } \\
\cdot \\
\cdot\end{array}$ & & . & . & & $\begin{array}{l}\text { n.s. } \\
\text { n.s. }\end{array}$ \\
\hline $\begin{array}{l}\text { Diagnostic species of the class } M u \\
\text { Viola biflora } \\
\text { Rumex alpestris } \\
\text { Primula pallasii }\end{array}$ & $\begin{array}{l}\text { lgedio-Ac } \\
51^{0.18} \\
43^{0.15}\end{array}$ & $\begin{array}{l}\text { nitetea } \\
48^{0.31} \\
60^{0.2}\end{array}$ & $\begin{array}{c}16^{0.23} \\
47^{+} \\
13^{+}\end{array}$ & $\begin{array}{c}14^{0.36} \\
79^{0.27} \\
\cdot\end{array}$ & $\begin{array}{c}69^{0.49} \\
15^{+}\end{array}$ & $\begin{array}{c}26^{0.13} \\
63^{0.16} \\
\end{array}$ & $42^{+}$ & & $\begin{array}{l}\text { n.s. } \\
\text { n.s. } \\
\text { n.s. }\end{array}$ \\
\hline
\end{tabular}


layer. The Cyrsium helenioides-comm. comprised very tall forb-communities.

The following F and G clusters constituted a separate subclade and correspond to two different community types.

There were three indicator species for Calamagrostis purpurea-community type (cluster F). The most significant indicator was the well pronounced dominant species Calamagrostis langsdorffii. Mean elevations were most typical for the Calamagrostis purpurea-comm. within the study area, but we also found a few stands at higher elevations (until $1537 \mathrm{~m}$ a.s.l.) in appropriate habitats. Stands belonging to this community type occupied naturally disturbed places, usually along avalanche-prone areas. Thus, they developed at rather steep slopes of southward oriented aspect. The height of the herb layer had mean values regarding the other established clusters.

Pteridium aquilinum was the main dominant species in communities of the cluster $\mathrm{G}$ (Pteridium aquilinum-comm.). There were another four indicator species, most of them are typical forest plants. This community type was characterized by high species richness. The importance of forest species reflects a confinement of these communities to lower elevations, lowest within the data set. The Pteridium aquilinum-comm. occurred at medium steep and smooth slopes of warmer southern aspect and occupy habitats with thick organic layer.

The general pattern of the tall-herb vegetation within the study area was following. Right above the timberline, the large habitats of the Pteridium aquilinum-comm. were developed. Disturbed slopes of southern aspect at different elevations were occupied by stands of the Calamagrostis purpurea-comm., the Athyrium distentifolium-comm. and the Oreopteris limbosperma-comm. occupied the lower and the middle parts of the slopes mainly in central part of the subalpine belt. Stemmacantha carthamoides-comm. vegetation developed at highest elevations and steepest slopes of valley boards. At similar elevations, but on more gentle slopes, stands of the Veratrum lobelianum-comm. are found. Cirsium helenioides-comm. were typical for banks of streams and streamlets.

\section{Ordination}

The established model for the canonical correspondence analysis included elevation, aspect (modified), inclination, microtopography and organic layer as environmental va- riables $(\mathrm{p}<0.05)$ (Fig. 5). Because of NA-values, 15 relevés have been removed from the analysis. The performed CCA showed a total inertia of 3.58, from which $21.7 \%$ was explained. The eigenvalue for the first constrained axis is 0.30 , for the second 0.28 and the third 0.08 . The CCA ordination was consistent with results of the cluster analysis and stresses the contribution of different ecological factors of the distinguished community types.

The strong positive correlation with microtopography of Atbyrium distentifolium-comm. and Cirsium belenioidescomm. was determined by their confinement to stony habitats. In a complex together with Oreopteris limbospermacomm., these community types were negatively correlated with aspect, which means, they avoid warmer slopes and prefer north-eastern or even northern aspect. A strong positive correlation of the Stemmacantha carthamoides-comm. with higher elevations, and steeper slopes was also evident. In contrast to that, the Calamagrostis purpurea-comm. and especially the Pteridium aquilinum-comm. avoid high elevations but were positively correlated with warmer southern and south-western aspect, as well as a well-formed

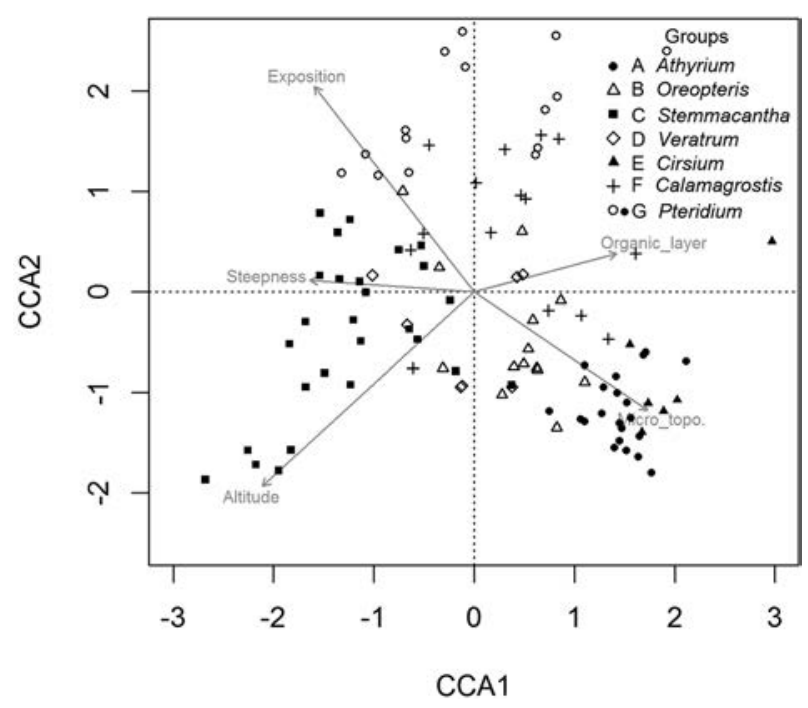

Figure 4 Canonical correspondence analysis ordination diagram for sampled relevés. Differences in sample symbols correspond to distinguished clusters. Arrows indicate the influence of environmental factors

\footnotetext{
Other species occurence (\%): Abies sibirica (sl): B - 4, C - 3, D - 7; Aconitum glandulosum: A - 3, B - 8, C - 16, F - 32, G - 13; Aconogonon alpinum: C - 9; Allium chamarense: B - 4, C - 41, D - 14, E - 8, F - 5, G - 17; A. microdictyon: A - 34, B - 40, C - 3, D - 57, E - 54, F - 21, $\mathrm{G}-29$; Anemone altaica: A - 6, B - 4, C - 6; A. baicalensis: A - 40, B - 56, D - 57, E - 54, F-32, G - 58; A. reflexa: C - 3; Antennaria dioica: C- 9; Artemisia integrifolia: $\mathrm{G}-4 ;$ A vulgaris: $\mathrm{F}-5, \mathrm{G}-4$; Bergenia crassifolia: $\mathrm{A}-6, \mathrm{~B}-12, \mathrm{C}-31, \mathrm{~F}-26, \mathrm{G}-4$; Betula cf. $\times$ irkentensis (sl): $\mathrm{F}$ $-11, G-4 ;$ Bistorta major. F - 5, G - 4; B. vivipara: $G-8$; Brachypodium sylvaticum: $G$ - 4; Calamagrostis obtusata: $G$ - 8; Cardamine macrophylla: E - 23; Carex aterrima: A - 3, B - 8, D - 7; Cerastium davuricum: A - 3, E - 8, F-11, G - 8; C. pauciflorum: G - 4; Circaea alpina: A - 9, E - 8; Dactylorbiza fuchsii: A - 3, B - 12, C - 34, D - 7, F - 5, G - 21; Dracocephalum nutans: C - 6, G - 4; Dryopteris expansa: A - 9, D - 7, F - 11; D. filix-mas: A - 3, E - 8, F - 5, G - 8; Duschekia fruticosa (sl): A - 6, B - 4, C - 3; Equisetum sylvaticum: E - 15; Eranthis sibirica: A - 37, B - 32, $\mathrm{C}-28, \mathrm{D}-50, \mathrm{E}-31, \mathrm{G}-17$; Euphrasia syreitschikovit: $\mathrm{C}-25, \mathrm{~F}-5, \mathrm{G}-4$; Gymnadenia conopsea: $\mathrm{C}-6$; Hieracium tunguskanum: $\mathrm{C}-9, \mathrm{G}-8$; Kiaeria blyttii $(\mathrm{ml}): \mathrm{D}-7$; Lescuraea saxicola $(\mathrm{ml}): \mathrm{C}-3$; Lycopodium clavatum: $\mathrm{C}-9$; Matteuccia strutbiopteris: $\mathrm{G}-4$, Melica nutans: $\mathrm{F}-5$, G - 8; Moerckia blyttii (ml): D - 7; Oberna behen: C - 31, D - 21, F-11, G - 17; Padus avium (sl): F - 5, G -4; Parasenecio hastatus: G - 8; Paris quadrifolia: A - 9, D - 29, E - 23, F-26, G - 38; Parnassia palustris: B - 4, C - 13; Patrinia sibirica: C - 3; Pedicularis compacta: C - 6, D - 7; P. verticillata: C - 6; Phegopteris connectilis: A - 3, B - 44, C -34, D - 21, F - 63, G - 71; Phyllodoce caerulea: C - 22; Pinus pumila (sl): C - 3; Pulsatilla patens: B - 4 C-9; Ranunculus propinquus: B - 8, C - 53, D - 14, E-8, F-16, G-13; Rubus arcticus: G - 4; R idaeus (sl): A - 9, E-8, F-5, G-13; Salix caprea (sl): G - 4; Saussurea parvifora: F - 11, G - 13; Saxifraga spinulosa: C - 9; Sibbaldia procumbens: C - 19; Silene amoena: F - 5; Sorbus sibirica, (sl): B - 4, G - 4; Syntricbia ruralis (ml): C - 3, E - 8; Tanacetum vulgare subsp. boreale: $C-6, G-4$; Tephroseris praticola: $B-4, G-4 ;$ Thesium repens: $\mathrm{B}-4, \mathrm{C}-22, \mathrm{G}-4$; Trientalis europaea: $\mathrm{A}-17, \mathrm{~B}-12, \mathrm{C}-6, \mathrm{E}-8, \mathrm{~F}-11$; Valeriana transjenisensis: $\mathrm{B}-4, \mathrm{C}-3, \mathrm{E}-8, \mathrm{~F}-5, \mathrm{G}-13$; Veronica densiflora: $\mathrm{C}-6, \mathrm{G}-4$; Viola uniflora: $\mathrm{B}-8, \mathrm{C}-13, \mathrm{G}-8$.
} 
organic layer. The Veratrum lobelianum-comm. did not show a strong correlation with any factors analyzed and located around the center of the diagram.

\section{DISCUSSION \\ Floristic diversity}

Regarding floristic diversity, it is worth to stress that only 33 species of 132 species listed in our data set have constancy-values higher than I class, i.e. recorded in more than $20 \%$ of plots. A similar pattern was noted by Korolyuk (Korolyuk 2001) for tall-herb vegetation in Katunskii Nature Reserve (Altai Mts.). He suggested that the local diversity of dominant combinations in subalpine meadows comes amid the monotony of a comparatively low number of species (Korolyuk 2001). Although, this pattern could also be related to the dataset, as the number of species with higher frequency will decrease with addition of new data.

Higher species richness was confined to the warmest slopes with inclinations from 10 to 30 degrees of south and south-west aspect, where the topography helps to reduce superfluous soil moisture and shorten the period of snow cover. As topography is influencing snow layer in alpine regions, it evokes environmental gradients within rather small areas (Billings \& Bliss 2017). Due to aspect to the sun, a longer growing season can be suggested for the species in floristically richest community types, i.e. Stemmacantha carthamoides-comm. at higher elevations and Calamagrostis purpurea-comm. and the Pteridium aquilinum-comm. at lower part of the subalpine belt. Besides that, Bowman (1992) supposed that vegetation below larger snow cover benefits from higher nutrient levels due to melting snow.

\section{Community types}

Tall-herb vegetation of the Bolshoi Mamai River could be clearly separated into seven community types, which were characterized by specific indicator species, in this study. We found the vegetation patterns to be strongly related to environmental factors as it was described for analogous tallherb vegetation in Europe (Odland et al. 1995, Karst et al. 2005).

First of all, the elevation was recognized as an important factor distinguishing different types of plant communities, which is consistent with other investigations in Southern Siberia (Ermakov et al. 2000) and in Europe (Michl et al. 2010). The Pteridium aquilinum-comm. was characteristic for lower part of the subalpine belt within the study area. Similar communities with dominance of Pteridium aquilinum are known for lower elevations in Europe, too (e. g. Watt 1940). The stands of the Stemmacantha carthamoides-comm. were typical for higher elevations. Definitely, other mountains of Southern Siberia are ecologically more comfortable for Stemmacantha carthamoides, where this species is treated as diagnostic one for a number of associations in lower, middle and upper part of the subalpine belt (Ermakov et al. 2000, Zibzeev 2010a). The elevation amplitude where subalpine meadows were described in the study area comprises 600$700 \mathrm{~m}$. The upper limit of their distribution was located at approximately $1600 \mathrm{~m}$ a.s.l. (see Tab. 1) reaching the watershed of the river basin. This distribution limit is linked to the height of the range, and not to physiological limits of the meadow plant species. For example, cryophilous tallforb vegetation on other South Siberian Ranges described at elevations from 800 till $1900 \mathrm{~m}$ (Ermakov et al. 2000), or even till $2400 \mathrm{~m}$ a.s.l. (Korolyuk 2001).

All tall-herb communities are very productive, forming a dense and high vegetation cover (Gjærevoll 1956, Ellenberg \& Leuschner 2010). For European stands of the species Athyrium distentifolium, for example, fronds with a size over $150 \mathrm{~cm}$ were recorded (Odland et al. 1995). The average height of Siberian tall-herb vegetation in general, as reported by Ermakov et al. (2000), was ranging between 80 and 140 $\mathrm{cm}$ but can reach up to $250 \mathrm{~cm}$. In our study area, subalpine meadows are notably lower. Highest herb layer exceeding $100 \mathrm{~cm}$, could be only found in Athyrium distentifoliumcomm. and Cirsium helenioides-comm. Calamagrostis purpureacomm. and Pteridium aquilinum-comm. are respectively even lower by 30 and $20 \mathrm{~cm}$. The three other community types (Oreopteris limbosperma-comm., Stemmacantha carthamoidescomm., Veratrum lobelianum-comm.) did nearly never exceed a height of $50 \mathrm{~cm}$ and apparently present the most cryophilous subalpine meadows at higher elevations transitional between tall-herb subalpine and low-herb alpine meadows. Ermakov et al. (2000) consider such "middle-herb" meadows with a height of $40-80 \mathrm{~cm}$ in an order Schulzio crinitae-Aquilegietalia glandulosae (Ermakov et al. 2000). Despite the generally lower height of meadows in the study area, no community type from Bolshoi Mamai can be connected with the "middle-herb" order. Taking the revealed indicator species, and diagnostic species of the infraclass syntaxa into account (Ermakov et al. 2000), the distinguished community types belong to different alliances of the order Trollio-Crepidetalia sibiricae Guinochet ex Chytrý et al. 1993. The final syntaxonomic decision can be made after analysis of data from a wider area. Perhaps, the lowering of subalpine meadows in the Khamar-Daban Range in general, indirectly indicates the restrictions imposed by strong continental climate on the easternmost limit of tallherb vegetation distribution.

A well-formed organic layer (at least $2 \mathrm{~cm}$ thick) was characteristic for most clusters, considered in our study. As noted before, we consider the term "organic layer" in a broad sense, including proper organic (litter) and surface soil horizons. Plants growing in tall-herb communities should be adapted to a well formed litter layer. Not only dominant species, but also associated species have to develop strongly built shoots to get through the dense litter, as it was found for Anemone nemorosa in Europe (Al-Mufti et al. 1977). In the same time, the well-formed organic layer suggests stable conditions, which in turn lead to the advantage of more competitive species. Consequently, this variable is inversely proportional to the species richness (see Fig. 2). Only Stemmacantha carthamoides-comm. and Cirsium belenioidescomm. showed nearly no organic layer. Steep slopes and high elevations, where stands of Stemmacantha carthamoidescomm. usually occur, or habitats along wet streamlets typical for Cirsium helenioides-comm. might explain that fact. Both habitats are too unstable to enable the assembling of a thick organic layer, but regular disturbing facilitates introduc- 
tion of new species. As a result, Stemmacantha carthamoidescomm. and Cirsium helenioides-comm. are among the richest in species diversity.

In spite of the regularities revealed, the CCA ordination showed that over $70 \%$ of the variance remained unexplained. This suggests that other environmental variables, remaining outside the analysis, are important for ecological differentiation of community types of subalpine meadows. For example, the strong correlation of some clusters with microtopography, rather a composite environmental factor, suggests that importance of substrate stoniness is left underestimated. Important for the distribution of communities are also biotic interactions, like a competition (McGill et al. 2006), which were not investigated in this study.

\section{CONCLUSION}

We studied the local vegetation pattern of subalpine tallherb meadows on the Khamar-Daban Range, the easternmost limit of plant communities phytosociologically treated within the Eurosiberian class Mulgedio-Aconitetea Hadač \& Klika in Klika \& Hadač 1944. Due to broad distribution and comparatively rich vegetation diversity revealed on a small territory, the climatic conditions existing in the study area can be recognized as rather optimal for the development of subalpine tall-herb vegetation in a strong continental climate. Because of a large amplitude of elevation and different habitats in the subalpine belt of our study area, we found a comparatively high diversity of community types, which were floristically and ecologically distinguished in our research. We assume that the found community types can be a good basis for future syntaxonomic analyses of the tall-herb vegetation on the Khamar-Daban Range and that many of the indicator species will be accepted as diagnostic species.

\section{ACKNOWLEDGEMENTS}

We are grateful to Sergey Bystrov for participating in the fieldwork and providing three relevés used in this article; to Dolgor Tubanova for the determination of mosses; to Yuri Mamontov for the determination of liverwort specimens; and to Svetlana Solodyankina for making a map of the study area. We also thank Thilo Heinken and Norbert Hölzel for helpful advices concerning statistical analysis. We specially acknowledge Oleg Anenkhonov, Nikolai Lashchinskyi, Milan Chytrý as well as one anonymous reviewer for helpful comments on an early version of the article. The study was financially supported by the Russian Foundation for Basic Research (16-05-00783-a) and by Deutscher Akademischer Austauschdienst (DAAD) Promos Program. The research of V.V. Chepinoga was also carried out using the framework of project 0347-2016-003, supported by the Russian Federal Budget.

\section{LITERATURE CITED}

Al-Mufti, M., C. Sydes, S. Furness, J. Grime \& S. Band 1977. A quantitative analysis of shoot phenology and dominance in herbaceous vegetation. Journal of Ecology 65(3): 759-791.

Aleksandrova, G.K., O.S. Vizenko, N.P. Ladejschikov, K.N. Mizandrontseva \& L.P. Sorokina 1977. Thermal air regimes. In: Climate structure and resources at Baikal Lake and adjacet territories (N.P. Ladejschikov, ed.), pp. 71-93, Nauka, Novosibirsk. (in Russian). [Александрова Г.К., Виженко О.С., Аадейщиков Н.П., Мизандронцева К.Н. \& Сорокина А.П. 1977. Термический режим возАуха // Структура и ресурсы климата Байкала и сопредельных пространств / под реА. Н.П. Аадейщикова. Новосибирск: Наука. С. 71-93].

Banaš, M., M. Zeidler, M. Duchoslav \& J. Hošek 2010. Growth of alpine lady-fern (Atbyrium distentifolium) and plant species composition on a ski piste in the Hrubý Jeseník Mts., Czech Republic. Annales Botanici Fennici 47(4): 280-292.

Basargin, E.A. \& E.G. Zibzeev 2018. Vegetation MulgedioAconitetea class in the subalpine belt of Kuznetsky Alatau. Rastitelny Mir Aziatskoi Rossii 1: 38-36 (in Russian with English summary). [Басаргин Е.А., Зибзеев Е.Г. 2018. Растительность класса Mulgedio-Aconitetea в субальпийском поясе Кузнецкого А^атау // Растительный мир Азиатской России. № 1(29). С. 38-56].

Belov, A.V., L.P. Sokolova \& V.V. Chepinoga 2015. Vegetation. In: Geography of Siberia in the early 21st century. Vol. 2. Nature (Yu.M. Semenov \& A.V. Belov, eds), pp. 231-257, Geo, Novosibirsk (in Russian). [Белов A.B., Соколова А.П., Чепинога В.В. 2015. Растительность // География Сибири в начале XXI века. Т. 2. Природа / отв. ред. Ю.М. Семенов, А.В. Белов. Новосибирск: Гео. C. 231-257].

Billings, W.D. \& L.C. Bliss 2017. An alpine snowbank environment and its effects on vegetation, plant development, and productivity. Ecology 40:388-397.

Bowman, W.D. 1992. Inputs and storage of nitrogen in winter snowpack in an alpine ecosystem. Arctic and Alpine Research 24(3):211-215.

Chepinoga, V.V., M.V. Protopopova \& V.V. Pavlichenko 2017. Detection of the most probable pleistocene microrefugia on the northern macroslope of the Khamar-Daban Ridge (Southern Prebaikalia). Contemporary Problems of Ecology 10:38-42.

Chepinoga, V.V., N.V. Stepantsova, A.V. Grebenyuk, A.V. Verkhozina, O.P. Vinkovskaya, A.A. Gnutikov, N.A. Dulepova, I.V. Enushchenko, A.M. Zarubin, S.G. Kazanovsky, A.S. Konovalov, A.A. Korobkov, A.N. Luferov \& S.A. Rosbakh 2008. Check-list of the vascular flora of the Irkutsk region. Irkutsk State University Publishing, Irkutsk, 327 pp. (in Russian with English abstract). [Чепинога, В.В., Н.В. Степанцова, А.В. Гребенюк, А.В. Верхозина, О.П. Винковская, А.А. Гнутиков, Н.А. Аулепова, И.В. Енющенко, А.М. Зарубин, С.Г. Казановский, А.С. Коновалов, А.А. Коробков, А.Н. Ауферов, С.А. Росбах 2008. Конспект флоры Иркутской области (сосудистые растения). Иркутск, ИзА-во Иркут. гос. ун-та. 327 с.].

Chytrý, M., O.A. Anenchonov \& J. Danihelka 1995. Plant communities of the Bolšoj čivyrkuj river valley, Barguzinskij Range, East Siberia. Phytocoenologia 25(3):399-434.

Chytrý, M., P. Pešout \& O.A. Anenchonov 1993. Syntaxonomy of vegetation of svjatoj nos peninsula, Lake Baikal, 1. Non-forest vegetation. Folia Geobotanica et Phytotaxonomica 28:337-383.

Crawley, M.J. 2013. The R book. Second edition. John Wiley \& Sons, Chichester, West Sussex, UK. 1076 pp.

Danihelka, J. \& M. Chytrý 1995. Some plant communities of the Bol'šaja Čeremšana valley, Barguzinskij Range. Siberian Naturalist 1:165-202. Ninox Press, Praha.

Dargie, T.C.D. 1984. On the intergrated interpretations of 
indirect site ordinations: A case study using semi-arid vegetation in southeastern spain. Vegetatio 55:37-55.

Dierßen, K. 1996. Vegetation Nordeuropas. Ulmer, Stuttgart. 838 pp.

Dormann, C.F., \& I. Kühn 2009. Angewandte Statistik, für die biologischen Wissenschaften. 2., Aufl. Helmholtz Zentrum für Umweltforschung-UFZ, Leipzig. 245 S.

Dufrene, M. \& P. Legendre 1997. Species assemblages and indicator species: The need for a flexible asymmetrical approach. Ecological Monographs 67(3):345-366.

Ellenberg, H. \& C. Leuschner 2010. Vegetation Mitteleuropas mit den Alpen: In ökologischer, dynamischer und historischer Sicht. Eugen Ulmer Verlag, Stuttgart. 1334 S.

Elliott, K.J., J.M. Vose, W.T. Swank \& P.V. Bolstad 1999. Long-term patterns in vegetation-site relationships in a southern appalachian forest. Journal of the Torrey Botanical Society 126(4): 320-334.

Ermakov, N. 2003. Tall-forb communities of the north Altai. Annali die Botanica nuova serie 3: 23-34.

Ermakov, N., D. Shaulo \& T. Maltseva 2000. The class Mulgedio-Aconitetea in Siberia. Phytocoenologia 30(2):145-192.

Fahrmeir, L., C. Heumann, R. Künstler, I. Pigeot \& G. Tutz 2016. Statistik: Der weg zur datenanalyse. Springer-Verlag, Berlin, Heidelberg. $610 \mathrm{~S}$.

Florensov, N.A. 1974. Highlands of Zisbaikalia and Transbaikalia. Nauka, Moscow, 360 pp. (in Russian) [Фцоренсов Н.А. 1974. Нагорья Прибайкалья и Забайкалья. Москва: Наука. 360 с.].

Florensov, N.A. \& V.N. Olyunin 1965. Relief and geological structure. In: Pre-Baikal and Trans-Baikal (I.P. Gerasimov, ed.), pp. 23-90, Nauka, Moscow (in Russian). [ФАоренсов Н.А., Олюнин В.Н. 1965. Рельеф и геологическое строение // Предбайкале и Забайкале / под реА. И.П. Герасимова. Москва: Наука. С. 23-90].

Gjærevoll, O. 1956. The plant communities of the Scandinavian alpine snow-beds. F. Bruns, Trondheim. 450 pp.

Grabherr, G. \& L. Mucina 1993. Die Pflanzengesellschaften Österreichs. T. 2. Natürliche waldfreie Vegetation. Fischer, Jena.

Guinochet, M. 1982. Notes de phytosociologie sigmatiste prises en siberie meridionale. Documents Phytosociologiques 6: 295-301.

Hennig, C. 2018. fpc: Flexible Procedures For Clustering. R Package Version 2.1-11.1. URL: https://cran.r-project.org/ web/packages/fpc/fpc.pdf [last access 30.10.2018]

Horvat, I., V. Glavač, \& H. Ellenberg 1974. Vegetation Südosteuropas. Fischer, Stuttgart. $768 \mathrm{~S}$.

Iakushenko, D., M. Burlaka, I. Chornei, I. Kvarovska, V. Solomakha \& A. Koraryuk 2012. Syntaxonomy of subalpine tall-grass communities (Calamagrostietalia villosae) in the Ukranian districts of the Eastern Carpathians. Annali di Botanica (Roma) 2:67-78.

Ignatov, M.S., O.M. Afonina \& E.A. Ignatova 2006. Checklist of mosses of East Europe and North Asia. Arctoa 15:1-130.

Karst, J., B. Gilbert \& M.J. Lechowicz 2005. Fern community assembly: The roles of chance and the environment at local and intermediate scales. Ecology 86:2473-2486.

Kočí, M. 2001. Subalpine tall-forb vegetation (MulgedioAconitetea) in the Czech Republic: syntaxonomical revision. Preslia 73:289-331.
Konstantinova, N., V. Bakalin, E. Andreeva, A. Bezgodov, E. Borovichev, M. Dulin \& Y.S. Mamontov 2009. Checklist of liverworts (marchantiophyta) of Russia. Arctoa 18: $1-64$.

Körner, C. 1998. A re-assessment of high elevation treeline positions and their explanation. Oecologia 115:445-459.

Korolyuk, A. 2001. Vegetation. In: Flora and vegetation of the Katun natural reserve (Altai Mts.) (V.P. Sedelnikov, ed.), pp. 12-141, Nauka, Novosibirsk (in Russian). [KopoАюк А. 2001. Растительность // ФАора и растительность Катунского заповедника (А^тайские горы) / пол реА. В.П. Седельникова. Новосибирск: Наука. C. 12-141].

Korolyuk, A. 2006. Ecological optimum of south Siberian plants. In: Botanical investigations in Siberia and Kazakbstan. Irbis, Kemerovo, 12:3-28 (in Russian). [Королюк A. 2006. Экологические оптимумы растений юга Сибири / / Ботанические исследования Сибири и Казахстана. Ирбис, Кемерово. Т. 12. С. 3-28].

Ladeishchikov, N.P., A.H. Filippov, E.G. Zedgenidze, I.K. Zusman, V.A. Obolkin \& S. Reznikova 1977. Precipitation and moisture regime. In: Structure and resources of climate at Baikal lake and adjacet territories (N.P. Ladejschikov, ed.), pp. 98-125, Nauka, Novosibirsk (in Russian). [ $\Lambda \mathrm{a}-$ Аейщиков Н.П., Филиппов А.Х., Зедгенилзе Е.Г., Зусман И.К., Оболкин В.А., Резникова С. 1977. Осадки и режим увлажнения // Структура и ресурсы климата Байкала и сопредельных пространств / пол реА. Н.П. Аадейщикова. Новосибирск: Наука. С. 98-125].

Lashchinskiy, N.N. \& L.A. Gorshkova 1995. Notes on syntaxonomy of subalpine meadows of the Kuznetsky Alatau nature reserve. In: Biocenotic studies in the natural reserve "Kurneskii Alatau" (A.A. Vasilchenko \& N.N. Lashchinskiy, eds), pp. 35-41. Nauka, Novosibirsk (in Russian). [Аащинский Н.Н., Горшкова А.А. 1995. Заметки по синтаксономии субамьпийских мугов заповедника Кузнецкого А^атау // Биоценотические исследования в заповеднике Кузнецкий Алатау / под реА. А.А. Васильченко, Н.Н. Аащинского. Новосибирск: Наука. С. 35-41].

Leyer, I. \& K. Wesche 2007. Multivariate statistik in der ökologie: Eine einfübrung. Springer, Heidelberg, Berlin. $221 \mathrm{~S}$.

Malyshev, L.I., K.S. Balkov \& V.M. Doronkin 1999. Spatial diversity of the siberian flora. Flora 194:357-368.

McGill, B.J., B.J. Enquist, E. Weiher \& M. Westoby 2006. Rebuilding community ecology from functional traits. Trends in Ecology \& Evolution 21:178-185.

McVean, D.N. \& D.A. Ratcliffe 1962. Plant communities of the Scottish Highlands. A study of Scottish mountain, moorland and forest vegetation. Her Majesty's Stationery Office, London. $445 \mathrm{pp}$.

Michl, T., J. Dengler \& S. Huck 2010. Montane-subalpine tall-herb vegetation (Mulgedio-Aconitetea) in central Europe: Large-scale synthesis and comparison with northern Europe. Phytocoenologia 40:117-154.

Odland, A. 1981. Pre- and subalpine tall-herb and fern vegetation in Roeldal, W-Norway. Nordic Journal of Botany 1: 671-690.

Odland, A., H.J.B. Birks \& J.M. Line 1995. Ecological optima and tolerances of Thelypteris limbosperma, Atbyrium distentifolium, and Matteuccia struthiopteris along environmental gradients in western Norway. Vegetatio 120: 115-129.

Oksanen,J.F., G. Blanchet, M. Friendly, R. Kindt, P. Legendre, 
D. McGlinn, P.R. Minchin, R.B. O'Hara, G.L. Simpson, P. Solymos, M.H.H. Stevens, E. Szoecs \& H. Wagner 2018. Vegan: Community ecology package. R package version 2.5-3. URL: https://cran.r-project.org/web/packages/ vegan/index.html. [last access 30.10.2018].

Pott, R. 1995. Die Pflanzengesellschaften Deutschlands. Ulmer, Stuttgart. $622 \mathrm{~S}$.

R Core Team 2018. R: A language and environment for statistical computing. $\mathrm{R}$ foundation for statistical computing. URL: https://www.R-project.org/, Vienna. [last access 30.10.2018].

Rivas-Martínez, S., T.E. Díaz, J.A.F. Prieto, J. Loidi \& A. Penas 1984. Los Picos de Europa. La vegetacion de la alta montaña Cantabrica. Editiones Leonesas, Leon. 295 pp.

Roberts, D.W. 2016. labdsv: Ordination and Multivariate Analysis for Ecology. R package version 1.8-0. URL: https://cran.rproject.org/web/packages/labdsv/index.html [last access 30.10.2018].

Rousseeuw, P.J. 1987. Silhouettes: A graphical aid to the interpretation and validation of cluster analysis. Journal of Computational and Applied Mathematics 20:53-65.

Sneath, P.H. \& R.R. Sokal 1973. Numerical taxonomy. The principles and practice of numerical classification. W. H. Freeman, San Francisco. 573 pp.

Strelkov, S.A. \& V.V. Vdovin 1969. Altai-Sayan mountain area. Nauka, Moscow. 413 pp. (in Russian). [Стрелков C.A., ВАовин В.В. 1969. А^тае-Саянская горная область. Москва: Наука. 413 с.].

Sulejman, R. 2011. Phytogeographic and syntaxonomic diversity of high mountain vegetation in Dinaric Alps (Western Balkan, SE Europe). Journal of Mountain Science 8(6):767-786.

Tubanova, D., O.M. Afonina, V.E. Fedosov \& V.V. Chepinoga 2016. New moss records from Republic of Buryatia, 10. New bryophyte records 6. Arctoa 25:218-219.

Valachovič, M., O.A. Anenkhonov \& I. Hodalova 2002. Vegetation along an altitudinal gradient in the Gremyachaya Valley, Barguzinskii Range, Eastern Siberia. Biologia 57:83-100.

Vries, A.D. \& B.D. Ripley 2016. Ggdendro: Tools for extracting dendrogram and tree diagram plot data for use with ggplot2. $\mathrm{R}$ package version 0.1-20. URL: https:// cran.r-project.org/ package $=$ ggdendro. [last access 30.10.2018].

Ward, J.H. 1963. Hierarchical grouping to optimize an objective function. Journal of the American Statistical Association 58:236-244.

Watt, A.S. 1940. Contributions to the ecology of bracken (Pteridium aquilinum). I. The rhizome. New Phytologist 39: 401-422.

Wickham, H. 2009. Ggplot2: Elegant graphics for data analysis. Springer, Berlin, Heidelberg. 212 pp.
Wickham, H. 2011. The split-apply-combine strategy for data analysis. Journal of Statistical Software 40(1):1-29.

Zeileis, A. \& G. Grothendieck 2005. Zoo: An s3 class and methods for indexed totally ordered observations. Journal of Statistical Software 14(6):1-27. URL: https://cran.rproject.org/web/packages/zoo/vignettes/zoo.pdf.

Zibzeev, E.G. 2010a. Classification of the vegetation of the subalpine belt of Ivanovskiy and Prokhodnoy ranges (Rudny Altai). Turczaninowia 13(3):12-28 (in Russian). [Зибзеев Е.Г. 2010. Классификация растительности субальпийского пояса Ивановского и Проходного хребтов (Рудный А^тай) // Turczaninowia. T. 13, № 3. C. 12-28].

Zibzeev, E.G. 2010b. The communities of the alliance Trollio asiaticae-Crepidion sibiricae Guinochet et Chytry et al. 1993 of the subalpine belts of the central part of Kryzhina ridge (Eastern Sayan). Vestnik. Novosibrskogo Gosudarstvennogo Universiteta. Seriya: biologiya, klinicheskaya meditsina 8(3):174-182 (in Russian with English summary). [Зибзеев Е.Г. 2010. Сообщества союза Trollio asiaticae-Crepidion sibiricae Guinochet et Chytry et al. 1993 субальпийского пояса центральной части хребта Крыжина (Восточный Саян) // Вестник Новосибирского государственного университета. Серия: биология, клиническая медицина. Т. 8, № 3. С. 174-182].

Zibzeev, E.G. 2012. Landscape forming high mountain communities of southern macroslope of the Terektinskiy Ridge (Central Altai): Classification, ecological and phytocoenotic characteristics. Turczaninowia 15(3):83-108 (in Russian). [Зибезиев Е.Г. 2012. АанАшафтообразующие высокогорные сообщества южного макросклона Теректинского хребта (Центральный Алтай): классификация, эколого-фитоценотическая характеристика // Turczaninowia. T. 15, № 3. С. 83-108].

Zibzeev, E.G. \& E.A. Basargin 2012. Classification and the coenotic characteristic of some tall-forbs communities of humid high mountains Western Sayan). Vestnik Novosibrskogo Gosudarstvennogo Universiteta. Seriva: biologiya, klinicheskaya meditsina 10(2):41-47 (in Russian). [Зибзеев Е.Г., Басаргин Е.А. 2012. Классификация и ценотическая характеристика некоторых высокорослых сообществ влажных высоких гор запаАной части Саяна // Вестник Новосибирского госуАарственного университета. Серия: биология, клиническая медицина. Т. 10, № 2. С. 41-47].

Zverev, A.A. 2007. Information technologies in studies of vegetation: Tutorial. TML Press, Tomsk. 304 pp. (in Russian). [Зверев, А.А. 2007. Информационные технологии в исследованиях растительного покрова: Руководство. Томск: ТМ $\Lambda$ Пресс. 304 c].

Zverev, A.A. 2012. Use of equivalence classes and factor sets in the analysis of botanical data. Contemporary Problems of Ecology 5(2):165-173. . 